\title{
„Co by było, gdyby...", czyli o (dwóch) możliwych, a niezrealizowanych historiach emigracyjnych
}

\section{Beata Dorosz}

(Instytut Badań Literackich PAN, Warszawa)

W październiku 2016 r. odbyła się konferencja naukowa Debata o „Kulturze”. Spothania i reminiscencje w 7o. rocznice powstania Instytutu Literackiego. Rzym-Paryż - Łódź, zorganizowana przez Fundację Kultury Paryskiej, Stowarzyszenie Instytut Literacki Kultura oraz Uniwersytet Łódzki. Miałam zaszczyt brać udział w panelu zatytułowanym Dorobek literacki Instytutu Literackiego w Paryżu, wcześniej zaś moderator panelu sugerował, bym skupiła się na „relacjach Instytutu Literackiego z ośrodkiem londyńskim".

Podjęcie takiej próby byłoby przysłowiowym wyważaniem otwartych drzwi, istnieją bowiem dwa obszerne szkice autorstwa świetnych znawców przedmiotu - i to w dwóch profilach badawczych: literaturoznawcy i historyka - mowa o studium Andrzeja S. Kowalczyka Jerzy Giedroyc - Mieczystaw Grydzerwski: dwa style bycia emigrantem ${ }^{\mathrm{I}}$ oraz rozprawie Rafała Habielskiego Mapa Maisons-Laffitte (Giedroyc i Londyn)2. Do ustaleń obu badaczy nie sposób dodać cokolwiek nowego i odkrywczego.

Można by - rzecz jasna - potasować nieco karty z wydanej korespondencji redaktora Giedroycia z jego najbliższymi współpracownikami i powybierać różne smakowite określenia i ciekawostki na temat Grydzewskiego i środowiska „Wiadomości”; potwierdziłoby to tylko utrwalone już przekonanie, że mamy poniekąd do czynienia z powtórką z historii Wielkiej Emigracji i romantycznego konkurowania

1 A.S. Kowalczyk, Jerzy Giedroyc - Mieczystaw Grydzerwski: dwa style bycia emigrantem, w: idem, Od Bukaresztu do Laffitów: Jerzego Giedroycia rzeczpospolita epistolarna, Sejny 2006, s. 105-120.

2 R.Habielski,Mapa Maisons-Laffitte (Giedroyc iLondyn), w: Jerzy Giedroyc:kultura-polityka-wiek XX, pod red. A. Mencwela, Warszawa 2009, s. 339-367. 
Mickiewicza ze Słowackim: „Dwa na słońcach swych przeciwnych - Bogi”, jak czytamy w Beniowskim.

Truizmem będzie przypomnienie, że Giedroyc nie darzył sympatią ani przedwojennych „Wiadomości Literackich”, ani „Wiadomości” londyńskich. O pierwszych mówił w Autobiografii na cztery ręce, że nie lubił ich „za pięknoduchostwo, za nieustanne szukanie «smaczków», za brak jakiejkolwiek linii”, uznając, że było to „pismo bez kręgosłupa”. I dodawał:

\section{\Po wojnie zaś „Wiadomości” stały się pismem po prostu endeckim, symbolem polskiego Londynu. Nie znosiłem ich więc z powodów przeciwnych tym, dla których nie lubiłem ich przed wojną ${ }^{3}$.}

Tu na marginesie warto dodać, że inni krytycy Grydzewskiego i londyńskich „Wiadomości” zarzucali mu dla odmiany właśnie apolityczność i „eklektyzm”, bo redaktor otworzył jego łamy dla wszystkich, bez względu na ich przedwojenną przynależność organizacyjną lub wyznawane poglądy na sztukę. Habielski stwierdza zatem, że „wśród czasopism emigracyjnych «Wiadomości» były jedynym periodykiem niemal w pełni odbijającym różnorodność $\mathrm{w}$ jedności świata wychodźczego"4.

Krytyka konkurencyjnego pisma nie przeszkadzała wszakże Giedroyciowi na wyrażanie z czasem uznania dla jego redaktora, gdy m.in. sugerował Gombrowiczowi napisanie okolicznościowego tekstu na 40-lecie „Wiadomości”. Kowalczyk cytuje nieopublikowany $\mathrm{w}$ wydaniu książkowym, a zachowany $\mathrm{w}$ archiwum Instytutu Literackiego list Giedroycia do Gombrowicza z 25 marca 1964 r.:

\section{\Jak wiesz, mój stosunek do Grydzewskiego i do „Wiadomości” był (już przed wojną) i jest najbardziej negatywny. To okropne i szkodliwe pismo. Niemniej redagowanie przez 40 lat pisma, które w pewnym sensie było dla dużego odłamu inteligencji pismem czołowym, jest swego rodzaju wyczynem sportowym i zapewne rekordem w skali europejskiej ${ }^{5}$.}

Redaktor Grydzewski natomiast, niejednokrotnie nagabywany przez Jana Lechonia o opinię na temat paryskiego pisma, wyznawał bez ogródek:

3 J. Giedroyc, Autobiografia na cztery ręce, oprac. K. Pomian, Warszawa 1994, s. 166.

4 R. Habielski, Nieztomni nieprzejednani. Emigracyjne "Wiadomości” i ich krag 1940-1981, Warszawa 1991, s. 7-8.

5 Cyt. za: A.S. Kowalczyk, Od Bukaresztu do Laffittów, op. cit., s. 109. 
\ „Kulturę” zawsze przerzucam, poświęcając każdemu zeszytowi 33-54 sekund [...]. Co do Kazia [Wierzyńskiego - B. D.], nigdy nie rozumiem, dlaczego ogłaszał tam wiersze ${ }^{6}$.

Wszystko to wiemy już od dawna. Przyszło mi zatem na myśl, by na te wzajemne relacje spojrzeć w stylu nieco à rebours, a po części także w konwencji tzw. historii alternatywnej - tj. „co by było, gdyby...” - aczkolwiek jestem świadoma ryzyka. Zachęca mnie jednak do tego znajomość niewydanej dotychczas korespondencji Grydzewskiego z Wierzyńskim (którą aktualnie przygotowuję do druku) oraz Giedroycia z Lechoniem. O tym zaś, jak ogromna siła tkwi w korespondencji jako źródle historycznym, nie trzeba nikogo przekonywać, choć należy zachować pewną ostrożność w jej interpretacji - bo my już w istocie wiemy, jak dalej potoczyła się historia, która w listach dopiero się dzieje.

A zatem: „co by było, gdyby...” Grydzewski poddał się roztaczanemu przed nim mirażowi i pod egidą 2. Korpusu rozpoczął po wojnie wydawanie pisma w Rzymie?

Do postawienia takiego pytania prowokuje kilka fragmentów z listów Grydzewskiego do Kazimierza Wierzyńskiego. Pisze bowiem Grydz do przyjaciela -7 grudnia $1945 \mathrm{r}$.:

》 Co do „Wiadomości” Borman alarmuje, bym pojechał do Rzymu, bo stamtąd można obsługiwać Francję i Niemcy, a wódz [generał Anders - B. D.] i wszyscy [...] palą się do tej imprezy. Nie mam wrażenia, by w Paryżu pismo dające porządną kontrparę mogłoby się utrzymać: po prostu by je zamknęli;

-30 grudnia $1945 \mathrm{r}$.:

\Co do zmartwychwstania „Wiadomości”, radość przedwczesna. Gotów jestem to zrobić, ale nie mam nikogo, kto by się zajął sprawami administracyjnymi, a ja na wszystko nie mam czasu. Liczyłem na Bormana, ale on się wyśmiewa ze mnie, twierdząc, że Włochy stanowią prawdziwe centrum życia, nie Londyn, i że tam jest wielkie pole działania. Zasadniczo zgodziliśmy się z Zygmuntem [Nowakowskim - B. D.] pojechać [...], ale wątpię, czy da się to technicznie przeprowadzić. A zresztą po nowej kapitulacji moskiewskiej myślę, że losy korpusu są przypieczętowane. Prędzej czy później;

6 List M. Grydzewskiego do J. Lechonia z 5 sierpnia 1954 r., w: M. Grydzewski, J. Lechoń, Listy 1923-1956, oprac. B. Dorosz, t. 2, Warszawa 2006, s. 265. 
- 6 stycznia I946 r.:

\) Rzym wydaje mi się bardzo problematyczny, mimo że zasadniczo się zgodziłem;

- I8 stycznia I946 r.:

\Włochy nie wydają mi się prawdopodobne, bo o ile szef popiera ten projekt, o tyle doły oenerowskie (Stahl) utrącają. Natomiast tutaj wyłaniają się coraz konkretniejsze możliwości nawet na tygodnik (z powodu ograniczeń papierowych na razie jedna kartka dawnego formatu) z matrycowaniem i rozsyłaniem matryc, gdzie się da. Ja zajmuję w tych wszystkich sprawach stanowisko raczej pasywne, bo boję się niewoli, związanej z wydawaniem tygodnika;

-26 lutego 1946 r.:

\J Jeżeli nie zajdzie coś nieoczekiwanego, rozpocznę „Wiadomości”. Jeżeli masz coś gotowego (to samo dotyczy Leszka7), przyślij - [...] nie zwracam się „oficjalnie”, bo naprzód muszę mieć stuprocentową pewność, że rzecz dojdzie na pewno do skutku. Jeżeli chcesz zaryzykować, by być w pierwszym numerze - będę Ci wdzięczny ${ }^{8}$.

Nie bez powodu tak eksponowane są tu daty listów odnoszących się do tych wydarzeń. Oto bowiem ir lutego I946 r. - czyli już po „włoskiej wyprawie” Grydzewskiego - generał Anders podpisał znamienny rozkaz, w którym czytamy:

\ Do organizacji Instytutu Wydawniczego w Rzymie wyznaczam: ppor. Giedrojć [sic!] Jerzego, Wąchala Władysława, Siuta Tadeusza.

W związku z tym polecam ppor. Wąchala Władysławowi przeprowadzić rozmowy i pertraktacje w sprawie kupna potrzebnej dla Instytutu drukarni oraz przedstawić mi akt kupna drukarni przed podpisaniem go przez zainteresowane strony. [...]

7 Mowa o Janie Lechoniu.

8 Wszystkie cytaty pochodzą z niepublikowanych listów Mieczysława Grydzewskiego do Kazimierza Wierzyńskiego, zachowanych w archiwum poety w Bibliotece Polskiej w Londynie, sygn.: 1360/Rps /VI/1.f1. 
Na pokrycie wydatków związanych z organizacją Instytutu i kupnem drukarni otworzone zostanie w jednym $\mathrm{z}$ banków włoskich konto, z którego pobierać będzie potrzebne sumy ppor. Wąchala Władysław za zgodą i aprobatą Szefa Służby Pieniężnej.

$\mathrm{Na}$ kupno drukarni przeznaczam sumę 8 o०० oo० lirów9.

Oficjalna informacja na stronie internetowej „Kultury Paryskiej” w zakładce „Historia” głosi, że „Instytut Literacki powstał w Rzymie przy 2. Korpusie Polskim na początku 1946 r. Dzięki pożyczce z funduszów 2. Korpusu Instytut Literacki kupił drukarnię, a wydawnictwo zarejestrowano jako Casa Editrice Lettere”. Wydaje się, że rozkaz generała Andersa rozstrzyga kwestie finansowe w kategoriach donacji czy wyasygnowania pieniędzy 2. Korpusu na cele wydawnicze, nie zaś jako pożyczkę na rzecz nowo powoływanego Instytutu Literackiego, ale zapewne za tą decyzją stały też inne, być może słowne, ustalenia między zainteresowanymi stronami. Kwestia subwencji bądź ewentualnej pożyczki została poruszona dopiero w dokumentach towarzyszących „Rozkazowi organizacyjnemu Instytutu Literackiego w Rzymie”, podpisanemu przez generała Andersa 28 września I946 r., jako na ów czas nierozstrzygnięta ${ }^{\mathrm{IO}}$. Dopiero za tym rozkazem poszła nominacja Jerzego Giedroycia na kierownika Instytutu, zawarta w osobnym piśmie datowanym 4 października 1946 r. ${ }^{\text {II }}$ Okres ten wspominał Giedroyc jako wcale nieoczywisty i raczej trudny:

\W okresie włoskim widziałem Andersa kilkakrotnie w sprawie konfliktów z cenzurą angielską. [...] Później byłem u niego w Londynie, m.in. w sprawie stworzenia Instytutu Literackiego. Nie był on entuzjastą tego projektu, gdyż wierzył w bliską wojnę, ale nie miał nic przeciwko temu i podpisał rozkaz powołujący do życia Instytut z moją nominacją na dyrektora. Interesowała go głównie nasza działalność usługowa w stosunku do wojska. Ale moich argumentów, że trzeba mieć jakieś bardziej długofalowe plany, nie przyjmował po prostu do wiadomości ${ }^{22}$.

Zbyt mało wiem o prehistorii „Kultury”, ale zaryzykuję pytanie: czyżby Giedroyc zagospodarował energię i fundusze, na które - obawiając się zależności, nie

9 Rozkaz w archiwum Instytutu Literackiego w Maison Laffitte, sygn. ILR 03 (nazwa zespołu i numer teczki: Instytut Literacki Rzym, t. 03).

10 „Rozkaz organizacyjny Instytutu Literackiego w Rzymie”, ibidem.

11 „Rozkaz...”i nominacja reprodukowane są jako materiał ilustracyjny w: J. Giedroyc, Autobiografia na cztery rece, op. cit.

12 Ibidem, s. 114. 
tylko w sensie reżimu czasowego, jaki narzuca wydawanie pisma co tydzień - nie zdecydował się wcześniej Grydzewski? Jako okoliczności powołania Instytutu Literackiego i „Kultury” zadziałały też inne czynniki, brane przecież wcześniej pod uwage przez Grydzewskiego: demobilizacja 2. Korpusu oraz konieczność finansowego i organizacyjnego uniezależnienia się od wojska. Miały one wpływ także na decyzje Giedroycia, który szybko regulował zobowiązania finansowe, ale też wybrał Paryż, a nie Londyn na miejsce dalszego działania. Wiadomo również skądinąd ${ }^{\mathrm{I} 3}, \dot{z ̇ e}$ w planach Giedroycia na wydawanie periodyku jako możliwy termin inauguracji jawiła się późna wiosna (cokolwiek by to miało znaczyć) roku 1946, w istocie pierwszy numer „Kultury” ukazał się dopiero 20 czerwca I947 r. w Rzymie - pierwszy numer londyńskich „Wiadomości” Grydzewskiego nosił zaś datę 7 kwietnia $1946 \mathrm{r}$.

Może warto byłoby przyjrzeć się dokładniej wzajemnej korespondencji obu redaktorów z tego okresu? Wprawdzie zachowane w Archiwum Emigracji w Toruniu pięćdziesiąt trzy listy Giedroycia z lat I945-1977 mają raczej charakter korespondencji z redakcją „Wiadomości”; podobnie też w treści, choć znacznie skromniej ilościowo, przedstawia się zasób listów Grydzewskiego w Instytucie Literackim: zaledwie osiem listów - jeden z I945 r. do Giedroycia, siedem z lat 1946-1949, 195 I i 1968 do redakcji „Kultury”. Być może jakieś światło na kulisy tej sprawy rzuciłaby także korespondencja (czy też inny rodzaj dowodu na kontakty) Grydzewskiego z generałem Andersem - niestety, w Archiwum Emigracji zachowały się listy generała do redakcji mające oficjalny charakter i pochodzące z późniejszego okresu (osiem listów z lat 1948-1967). Niemniej nie można lekceważyć faktu podniesionego przez badacza działalności Grydzewskiego i znawcę emigracyjnych „Wiadomości” Mirosława A. Supruniuka, który stwierdził:

\section{\W lutym 1946 roku był już zdecydowany zorganizować redakcję i biuro w Londynie [...]. Jednak dopiero dzięki staraniom Adama Pragiera rząd RP wyłożył na potrzeby tygodnika 3000 funtów (250 funtów miesięcznie). Podobną sumę otrzymał Grydzewski jeszcze w roku następnym, lecz już w 1948 dotacja została wstrzymana ${ }^{\mathrm{I} 4}$.}

Warto pamiętać, że w kierowanym wówczas przez Pragiera Ministerstwie Informacji i Dokumentacji Giedroyc objął Departament Kontynentalny. Supruniuk

13 Wspominał o tym profesor Sławomir M. Nowinowski na łódzkiej konferencji w październiku $2016 \mathrm{r}$. w referacie Jerzy Giedroyc w 1946 roku, opierając się na źródłowych dokumentach archiwalnych.

14 M.A. Supruniuk, Wstęp, do: M. Grydzewski, Silva rerum, oprac. J.B. Wójcik, M.A. Supruniuk, Warszawa 2014, s. 105-106. 
potwierdza też poniekąd wyrażoną wcześniej intuicję, że jest prawdopodobne, iż odnowa Grydzewskiego przeniesienia się do Rzymu z ewentualną nową redakcją i dawnym archiwum „miała wpływ na powstanie Instytutu Literackiego i powołanie «Kultury»", nadto podnosi istotną kwestię:

\ Czy odmowa Grydzewskiego mogła mieć wpływ na późniejsze losy wzajemnej niechęci obu redaktorów i rywalizację o „dusze” emigrantów? Kto to może wiedzieć ${ }^{15}$.

Kolejne pytanie z serii „co by było, gdyby...” stawia przed nami korespondencja Giedroycia z Lechoniem dotycząca planowanej, a nie zrealizowanej wspó1pracy poety z paryskim miesięcznikiem. Skromna liczbowo (składają się na nią trzy listy Lechonia z lat 1948-1949 i dziewięć listów Giedroycia z lat 1946-I950), ale - jak się wydaje - ważna, pozostaje dotychczas rozpoznana w minimalnym stopniu.

Znana jest natomiast dobrze korespondencja Giedroycia z Gombrowiczem, w której m.in. nastąpiła w roku I955 taka oto wymiana zdań - Gombrowicz do redaktora:

》 „Kultura” nie powinna tolerować tego, co Grydz wyrabia z Lechoniem. Ostatecznie można by nad tym przejść do porządku, gdyby wieszcz miał najlżejsze kwalifikacje na to stanowisko, gdyby to miało jakiś grunt w opinii. Ale cyniczny proceder Grydza wynika z przeświadczenia, że można sterroryzować opinię, wmówić ludziskom, co się chce, i wyznaczyć emigracji wieszcza ukazem, wybrać jakiegoś poecinę i powiedzieć: klękajcie! ${ }^{16}$

W odpowiedzi Giedroyc pisał:

\ Na Lechonia i na Grydzewskiego nie ma rady i - nie łudźmy się Grydz z Lechoniem są bardziej w guście rodaków niż my, np. „Kultura” to zawsze jakiś zapaszek żydomasoński, podejrzany, a tu wszystko proste, jasne ${ }^{\mathrm{I}}$.

15 Ibidem, s. 105.

16 List W. Gombrowicza do J. Giedroycia z 11 lutego 1955 r., w: J. Giedroyc, W. Gombrowicz, Listy 1950-1969, oprac. A.S. Kowalczyk, Warszawa 2006, s. 189.

17 List J. Giedroycia do W. Gombrowicza z 22 lutego 1955 r., w: ibidem, s. 192. 
Zmilczał też Giedroyc, gdy na łamach „Kultury” Marian Pankowski zszedł poniżej pewnego poziomu kultury i wrażliwości, nazywając Lechonia „tragikomiczną ciotą"18 , co wyjątkowo oburzyło Andrzeja Bobkowskiego ${ }^{\text {I9 }}$.

Dobrze rokujące początkowo kontakty Giedroycia i Lechonia zerwał poeta w maju 1949 r. listem krytycznym wobec linii politycznej „Kultury”, który Giedroyc ironicznie określał „listem pasterskim”, wzywającym, „by zawrócił z błędnej drogi”” .

Czy określenie „dobrze rokujące kontakty” jest w tym wypadku uprawnione? Odpowiedzią na to pytanie może być treść listów wymienianych między redaktorem a poetą.

Gdy w roku 1946 Giedroyc przesłał właśnie Lechoniowi do Nowego Jorku projekt planu wydawniczego i „deklarację ideową” Instytutu Literackiego, bez wątpienia liczył na intensywną współpracę z nim i Kazimierzem Wierzyńskim, trwał bowiem w przekonaniu, że ich nazwiska mogą zapewnić i wydawnictwu książkowemu, i planowanemu periodykowi lepszy start w różnych kręgach polskiej emigracji. Habielski wręcz twierdzi, że Giedroyc

\ odczuwał zazdrość o sukcesy „Wiadomości”, które w okresie powojennego dziesięciolecia zdawały się mieć większy wpływ na sposób myślenia emigracji niż zaczynająca dopiero promieniować „Kultura” ${ }^{21}$.

Na marginesie można dodać, że w nieco późniejszym okresie redaktor „Kultury” Z wyraźną niechęcią przyjmował fakt drukowania tekstów przez niektórych „swoich” autorów na łamach „Wiadomości, mając apetyt na wyłączność. Nie udało mu się to wobec wielu - jednym z najbardziej znaczących współpracowników obu pism

18 M. Pankowski, Wolny od tzy, „Kultura” 1957, nr 7-8. Tekst był recenzją wydanej przez Instytut Literacki książki Leo Lipskiego Dzień i noc (Paryż 1957), a czytamy w nim m.in.: „Książka ta przejdzie bez echa w Kraju, gdzie znana wszystkim prawda nie może być wspominana pełnym głosem. Nie sięgnie też po nią czytelnik emigracyjny, karmiony Maciusiem na szaro i mądrością, wiejącą z kart tragikomicznej cioty, Lechonia".

19 W liście do Giedroycia z 25 lipca 1957 r. Bobkowski pisał m.in.: „Dostałem podwójny numer «Kultury» i trochę się na Pana wściekłem, bo po co Pan puszcza temu Pankowskiemu takie odezwanie się o Lechoniu «ta tragikomiczna ciota». Panie Jerzy - to jest wstrętne. Niech go atakują za jego wiersze, zgoda, można mu odmówić talentu i w ogóle wszystkiego, ale dlaczego tak ordynarnie i po chamsku naśmiewać się z jego zboczenia, z jego homoseksualizmu? Bo «tragikomiczna ciota» nie ma nic wspólnego z Lechoniem pisarzem [...]. Mam zamiar przesłać bardzo opanowany list na ten temat do Redakcji. Czy mi Pan wydrukuje? Mam tym bardziej prawo, bo sam nigdy nie byłem pederastą i żadnych skłonności ku temu nie miałem. Równie dobrze można by wobec tego napisać ten «tragikomiczny pedzio» Michał Anioł”, cyt. za: J. Giedroyc, A. Bobkowski, Listy 1946-1961, oprac. J. Zieliński, Warszawa 1997, s. 468.

20 List J. Giedroycia do M. Wańkowicza z 8 sierpnia 1949 r., w: J. Giedroyc, M. Wańkowicz, Listy 1945-1963, oprac. A. Ziółkowska-Boehm, J. Krawczyk, Warszawa 2000, s. 87.

21 R. Habielski, Mapa Maisons-Laffitte (Giedroyc i Londyn), op. cit., s. 365. 
równocześnie był Kazimierz Wierzyński, którego 4 września 1948 r. Giedroyc strofował: „Wierność Pana dla Grydzewskiego jest wręcz irytująca”².

U zarania działalności Instytutu Literackiego pisał więc redaktor „Kultury” 8 lutego 1947 r. do Lechonia:

\section{\Szanowny i Drogi Panie,}

Bardzo nas tu wszystkich niepokoiły wiadomości o złym zdrowiu Pana. Mamy jednak nadzieję, że stan już się poprawił. W każdym razie będę zobowiązany za parę słów informacji.

Nie orientuję się w Pana planach i zamierzeniach literackich. Ale interesuje nas bardzo, czy Pan zamierza wydać zapowiadaną swego czasu książkę (której fragment był w „Wiadomościach Polskich”) pt. Bal u senatora. Jeśli rękopis jest gotowy i nie ma Pan innych propozycji wydawniczych, bardzo bym się cieszył, gdybym mógł być jej wydawcą. Może ma Pan inne rękopisy? Instytut Literacki pomału się rozkręca, jakkolwiek przeżywamy bardzo ciężkie trudności. Nie tylko natury „uchodźczej”, ale również z powodu kurczenia się czytelnictwa. Spowodowane jest to w głównej mierze pauperyzacją emigracji i skończeniem się „,bogatego rynku”, jakim było wojsko. Jednak przyzwyczajenie do książki zostało. Trzeba dać tylko książkę tanią. Bardzo się nad tą sprawą biedzimy.

Nie piszę nic o naszym kwartalniku, gdyż obszernie w tej sprawie pisał do Pana Herling-Grudziński. Bardzo liczymy na Pana współpracę. Łączę wiele serdeczności i proszę o parę słów odpowiedzi ${ }^{23}$.

\section{U najwcześniejszych zaś początków „Kultury” Giedroyc pisał II grudnia I947 r.} do Lechonia:

22 Oryginał listu w archiwum Kazimierza Wierzyńskiego w Bibliotece Polskiej w Londynie, sygn. 1360/Rps/VI/1e. - O relacjach Giedroycia z Wierzyńskim pisałam w tekście Poeta „do ustug” w objeciach „wielkiego manipulatora" (na marginesie korespondencji Kazimierza Wierzyńskiego z Jerzym Giedroyciem), „Sztuka Edycji” 2015, nr 2, s. 5-15; tu też w moim opracowaniu edytorskim: Listy Kazimierza Wierzyńskiego i Jerzego Giedroycia: cztery listy spośród czterystu czterdziestu listów, ibidem, s. 95-103.

23 W liście Herlinga, datowanym 3 stycznia 1947 r., czytamy: „Szanowny Panie, Instytut Literacki w Rzymie zamierza wydawać kwartalnik „Kultura”. Duża, książkowa objętość tego kwartalnika pozwoli na pomieszczenie w nim również rzeczy większych. W imieniu Komitetu Redakcyjnego zapraszam Pana gorąco do współpracy. Może ma Pan ochotę wydrukować większy fragment Balu u senatora? Termin nadsyłania prac do pierwszego numeru upływa 1 lutego". - List Giedroycia (maszynopis) i Herlinga-Grudzińskiego (rękopis) niepublikowane w całości; fragment cyt. w: W. Wyskiel, Kregi wygnania. Jan Lechoń na obczyżnie, Kraków 1988, s. 181; oba listy zachowane w archiwum Jana Lechonia w Polskim Instytucie Naukowym w Ameryce, kolekcja: Jan Lechoń Papers - 005, folder 22 i 28 . 
\Szanowny i Drogi Panie,

W tych dniach wysyłam Panu drugi numer „Kultury” i bardzo proszę o uwagi. Ponieważ od stycznia przekształcam „Kulturę” w miesięcznik i liczę się z tym, że będzie wychodziła regularnie, chcę Pana bardzo gorąco prosić o współpracę. Przede wszystkim ponieważ słyszałem, że pracuje Pan nad powieścią, proszę o jej fragment, mam zamiar bowiem w każdym numerze „Kultury” dawać dwa fragmenty prozy. Ale niezależnie od tego chciałbym się zapytać, czy nie zamierza Pan kontynuować swoich szkiców o literaturze polskiej. Gdyby takto może można byłoby zrobić to w ten sposób, że ukazywałyby się one w „Kulturze”, a potem wydałbym je w formie książkowej? Kontynuowanie tych szkiców miałoby przede wszystkim to duże znaczenie, że trafiłyby one do kraju, gdzie różnymi drogami, ale jednak „Kultura” w kilkuset egzemplarzach dochodzi. Ma się rozumieć, gdyby miał Pan inne projekty czy propozycje, to z góry się na nie zgadzam. Zaznaczam, że płacimy honoraria - chociaż skromne. Mam jeszcze jedną prośbę. Chciałbym w „Kulturze” postawić dobry dział recenzyjny, m.in. z literatury amerykańskiej. Zdaję sobie sprawę, że jest Pan zbyt zajęty, by zająć się tą sprawą specjalnie, ale może można by to było zorganizować w analogiczny sposób, jak to robią miesięczniki francuskie typu „Temps Modernes”, „Esprit” czy „Cheval de Troi”. Mianowicie szereg autorów jak Gide, Malraux, Maritain, Mauriac etc. przesyłają do nich krótkie notki z książek, które aktualnie przeczytali. Są to nie tyle recenzje, co myśli o danej książce, ale to może jest ważniejsze. Byłoby to dla nas ogromną pomocą. Prosząc o parę słów odpowiedzi, łączę serdeczne pozdrowienia ${ }^{24}$.

Wkrótce też nalegał ponownie, rozwijając wizję współpracy o nowe sugestie, zawarte w liście z 26 stycznia 1948 r.:

\) Drogi Panie,

Jestem bardzo niespokojny brakiem odpowiedzi Pana na mój ostatni list. Bardzo bowiem liczyłem na Pana cenną pomoc i współpracę. Dlatego pozwalam sobie raz jeszcze powtórzyć swoje prośby, a nawet wystąpić z nową propozycją. Mianowicie - niezależnie od fragmentu

24 List dotychczas niepublikowany; kopia maszynopisu w archiwum w Maison Laffitte: Korespondencja Redakcji - teka 409. ILK KOR RED. Lechoń. 
powieści Pana i szkiców o literaturze amerykańskiej ${ }^{25}$ - czy nie interesowałoby Pana opracowanie kilku szkiców o literaturze amerykańskiej? Myślę, że takie szkice są więcej niż potrzebne dla naszego życia kulturalnego. Wyobrażam sobie, że po wydrukowaniu w „Kulturze” wszystkich czy ich części - szkice wydalibyśmy jako książkę.

Bardzo prosząc o parę słów odpowiedzi, łączę wyrazy prawdziwego szacunku' ${ }^{26}$.

Lechoń odpowiedział z opóźnieniem, dopiero 20 marca I948 r., poruszając wszakże szereg ważnych dla Giedroycia zagadnień, a przy okazji wykładając swoje poglądy polityczne:

\section{\Drogi Panie,} jestem Panu winien wiele listów i byłbym spalił się ze wstydu na myśl o mej przewinie, gdyby nie świadomość, że miałem w tym czasie bez końca różnego gatunku komplikacji, niepozwalających mi na decyzje w sprawach, o których Pan pisał. „Kulturę” oczywiście otrzymuję i czytam z radością jako dziś obok „Wiadomości” jedyne wolne pismo polskie na świecie. Myślę też, że Pan je utrzyma - pomimo potwornego bezhołowia naszej emigracji, marnowania funduszów, które powinny by teraz wspierać naszą sprawę i pokazywać prawdziwą polską kulturę. Stąd rzeczy tak wyglądają, że pomimo wszystko po niemoralnie wygranej wojnie Ameryka będzie rządziła Europą i Europa będzie musiała przyjąć pewne rewolucyjne dla niej amerykańskie recepty polityki i gospodarki. O jakiejkolwiek w tych nowych uniformistycznych warunkach znaczniejszej roli Polski bez jej twórczego prymatu w kulturze i w pracy - mowy oczywiście nie będzie. Zna Pan moje przekonania i wie Pan, że nie jestem ani minimalistą, ani internacjonalistą, ale wydaje mi się to dość jasne, że sprawy granic zejdą na drugi plan przy tej właśnie konkurencji twórczości i pracy. I pomyśleć, że tutaj król Michał jest bohaterem demokracji, Czesi jej męczennikami a nas w ogóle nie ma poza Mikołajczykiem, który zresztą uważany jest przez Amerykanów za zupełnego idiotę. Bardzo chciałbym coś zrobić dla „Kultury”, ale boję się do czegokolwiek zobowiązywać - bo jestem pochłonięty pisaniem, chcąc nadrobić stracone lata i jakoś sobie życie zapewnić w tym potwornym opuszczeniu nas tutaj przez wszystkich

25 Tu pomyłka Giedroycia, który zapewne miał na myśli szkice o literaturze polskiej.

26 List dotychczas niepublikowany; kopia maszynopisu w archiwum w Maison Laffitte - jak w przypisie 24. 
i wszystko. Jeżeli chodzi o moją powieść - jeszcze nie doszedłem do jej przepisywania, co jest właściwie drugim pisaniem - kiedy będę w tym stadium, przyślę coś Panu, na razie wszystko co robię, musi być niestety obliczone na zarobek. - Mówię to Panu najszczerzej, bo to smutna prawda naszej egzystencji. Te studia o literaturze chcę teraz właśnie wznowić jako cykl odczytów w Nowym Jorku. Gdyby się tak stało, niektóre rzeczy dałbym do „Kultury” - o ile by Pan to chciał, bo każdy taki odczyt to dwadzieścia waszych kolumn, a rozbijać nie warto. Co do książki, to miałbym tom artykułów prozą, wspomnień, esejów, których pewnej stylistycznej i ideowej wartości nie chciałbym zagubić. Jest to łatwa lektura i gdyby Panowie na to wydanie reflektowali, mógłbym bardzo rychło taki tom przysłać. Jeśli chodzi o dalsze eseje - to przyznam się, że pomimo wszystko nie jestem dotąd dość dobrym ekspertem amerykańskich rzeczy. Natomiast zacząłem teraz jako pomoc w moim warsztacie pisarskim robić codziennie „Dziennik”, taki mniej więcej jak Gide. Sam nie wiem, czy wypadałoby to drukować w „Kulturze”. Może Pan mi napisze, co Pan o tym sądzi?

Myślałem dużo jak by to Wasze pismo rozpowszechnić - wydaje się to Wam pewno niepojęte, że mogą być z tym trudności. Otóż są i nic nie ma w świecie trudniejszego niż jakieś polskie zamierzenie kulturalne w Ameryce. Niech Pan spróbuje, nie powołując się na mnie, napisać do Instytutu Naukowego do pani Ireny Grabowskiej - i do panny Haliny Chybowskiej - 20 West 95 Street New York - z tego może wyjść trochę prenumerat. Ale myślę, że przy bardzo dobrej propagandzie - mogłoby to dojść do Ioo najwyżej.

Jestem pewny, że paru ludzi takich jak Pan i Czapscy, poparci Iooo [tysiącem] dolarów miesięcznie, mogliby tu zrobić wielkie rzeczy oczywiście wśród Amerykanów. Nic bardziej niepojętego niż kontrasty tego kraju, tych ludzi i tej kultury. Ameryka ma teraz film gorszy niż francuski i teatr najlepszy na świecie. Ona zrobiła Jałtę, ale przecież ona pobiła Hitlera i zniszczy Stalina. Jest to kraj Al Capona i Harry Hopkinsa, ale też kraj Wilsona i Whitmana. Fałszywi prorocy robią tu miliony, ale nie wątpię, że prawdziwi prorocy musieliby się tu bronić nie przed ukrzyżowaniem, ale przed ofiarowywanymi im miliardami. Czy nie możecie nic zrobić, aby tu się zakwaterowała sprawa polska i kultura polska? Czy naprawdę komedia polskiego gnilenia ${ }^{27}$ rządowego ma utłuc ostatnią szansę wprowadzenia Polski 
na godne miejsce w koalicji antyrosyjskiej? Bo jak tak dalej pójdzie będziemy musieli czepiać się Czechów i Rumunów.

Drogi Panie! Bardzo, bardzo dziękuję Panu, Pani Marii i Józiowi za depeszę $e^{28}$. Do Czapskich napiszę osobno - ale u mnie list to wielka i trudna awantura - więc może Pan byłby tak dobry i powiedział im na razie ode mnie najwdzięczniejsze słowa. Byłoby to bardzo po chrześcijańsku z Pana strony, gdyby Pan zrzekł się słusznej zemsty nade mną i rychło mi odpisał.

Wybierałem się wciąż do Paryża, ale teraz to już inna sprawa. Stąd rzecz wygląda tak - że jak najpóźniej - zaraz po wyborach ${ }^{29}$. I ja osobiście też tak myślę. Jeszcze raz dziękuję, przepraszam i łączę najserdeczniejsze wyrazy ${ }^{30}$.

Zaskakującą (z dzisiejszego punktu widzenia) propozycję publikowania dziennika Giedroyc przyjął z entuzjazmem; 9 kwietnia I948 r. pisał do Lechonia, odnosząc się też do innych poruszonych przez niego kwestii:

\section{》 Drogi Panie,}

Bardzo dziękuję za list z 20 marca, który dopiero wczoraj otrzymałem. Bardzo chętnie reflektuję na szkice o literaturze, o których Pan wspomina. To, że będą one tematem odczytu w St[anach] Zjednoczonych, nie będzie żadną przeszkodą, gdyż niestety obawiam się, że „Kultura” nie będzie na tamtym terenie cieszyła się zbyt wielką poczytnością.

Pomysł z „dziennikiem” à la Gide jest bardzo interesujący i bardzo bym na to reflektował. Rozumiem trudną sytuację, w jakiej dzisiaj wszyscy się znajdujemy, ale niewątpliwie sytuacja Panów w St[anach] Zjednoczonych musi być o wiele gorsza niż nasza. „Kultura” płaci jednak honoraria - choć niewielkie. Za szkice, o których Pan wspo-

28 Mowa o obchodzonej w Nowym Jorku 19 lutego 1948 r. uroczystości pod hasłem jubileuszu 30-lecia twórczości Jana Lechonia. Wspomniane depesze nie zachowały się w archiwum poety w Polskim Instytucie Naukowym (PIN), wiadomo jednak, że były odczytane na wstępie pośród innych telegramów gratulacyjnych - pisano o tym i wymieniono nazwiska wszystkich nadawców w reportażu sprawozdawczym (WB) [Wł. Borzęcki], Pięknie uczczono 30-lecie pracy twórczej Jana Lechonia, „Nowy Świat" (Nowy Jork) 1948, nr z 23 lutego.

29 Chodzi o wybory prezydenckie w USA, które w listopadzie 1948 r. wygrał reprezentant partii demokratycznej Harry S. Truman.

30 List dotychczas niepublikowany; rękopis w archiwum w Maison Laffitte: Papiery osobiste Jerzego Giedroycia - korespondencja. ILK PoJG 08.01. Lechoń; tekst zapisany rozstrzelonym drukiem $\mathrm{w}$ oryginale został podkreślony przez autora. 
mina, objętości mniej więcej 20 stron „Kultury” możemy płacić $5 £$., za „dziennik”, który zapewne będzie mniejszy - możemy dać $£ 3$.

Dziękuję za sugestie co do Instytutu Naukowego. Piszę jednocześnie do Pani Grabowskiej i p. Chybowskiej. Może z tego coś wyjdzie. Nawet w najlepszych marzeniach nie wyobrażam sobie, by można było w Ameryce zebrać więcej niż too prenumerat.

Niewątpliwie teren Stanów Zjednoczonych jest pasjonujący dla roboty polityczno-kulturalnej. By ją jednak tam prowadzić, trzeba mieć choć minimum pieniędzy, które by nie tylko pozwoliły żyć, ale również prowadzić chociażby najskromniejszą akcję. Tych pieniędzy z Czapskim nie mamy i nie ma żadnych widoków, by je dostać. Pieniądze rządowe się kończą, a jak są dysponowane i z jakim sensem, to nie potrzebuję chyba wspominać. Łączę bardzo serdeczne pozdrowienia i bardzo się będę cieszył, jeżeli zechce Pan zaszczycić „Kulturę” swoją współpracą ${ }^{3 \mathrm{I}}$.

Zaledwie dwa dni wcześniej, 7 kwietnia I948 r., pisał też redaktor do Lechonia:

1) Szanowny i Drogi Panie,

Nie zrażając się milczeniem Pana, występuję znów z prośbą i propozycją, czy interesowałoby Pana napisanie wiersza, związanego tematycznie z rocznicą bitwy o Monte Cassino. Chcielibyśmy zamiast oklepanych i tradycyjnych artykułów, jakie się zwykło w takie rocznice pisać, dać wiersz naszego największego poety.

Gdyby Pan zaakceptował naszą propozycję, proponuję honorarium $\mathrm{W}$ wysokości $5 £$. Wiersz byłby nam potrzebny przed końcem miesiąca.

Oczekując kilku słów odpowiedzi, łączę wyrazy prawdziwego poważania i serdeczne pozdrowienia ${ }^{32}$.

Otrzymawszy zaś utwór zatytułowany Nike spod Monte Cassino, I2 maja I948 r. pisał m.in.: „Dziękuję za śliczny wiersz. Idzie w nrze 7ym, który się za dwa dni ukazuje” (dodajmy, że był to ostatecznie jedyny tekst, jaki poeta opublikował na łamach paryskiego miesięcznika). W liście tym padła też jednocześnie inna propozycja dla Lechonia:

31 List dotychczas niepublikowany, kopia maszynopisu, zob. przypis nr 24.

32 Ibidem. 


\section{\ Nie wiem, czy dotarł do Pana list Iwaszkiewicza w „Nowinach Literac- kich" z 9 maja. Załączam więc wycinek. Gdyby chciał Pan odpowiadać publicznie, to łamy „Kultury” są do Pana dyspozycji33.}

Wydaje się, że nieprzypadkowo Giedroyc wybrał właśnie Lechonia na osobę, która miała dać właściwy odpór nachalnej propagandzie Iwaszkiewicza, skierowanej przeciwko emigrantom - ów „list” był to w istocie wiersz z cyklu Ody olimpijskie: Oda druga. Do dawnego zwycięzcy zawodów olimpijskich ${ }^{34}$ i choć pada w nim imię Kazimierza Wierzyńskiego i przywołany jest sukces jego Lauru olimpijskiego na igrzyskach w Amsterdamie, pytania i oskarżenia adresowane są do wszystkich, którzy nie zdecydowali się po wojnie na powrót do kraju35; prośby tej jednak poeta nie zrealizowat.

Z zachowanej korespondencji wynika, że kolejnym aktem w relacjach Giedroycia z Lechoniem był słynny już list poety na tematy polityczne. Komentowano go na różne sposoby (nie zawsze zgodnie z prawdą) ${ }^{36}$ i powoływano się nań wielokrotnie jako na przykład niezrozumienia przez Lechonia realiów powojennej polityki i stosunku emigracji do problemów krajowych, nigdy jednak nie był w całości publikowany ${ }^{37}$ - jest więc ku temu dobra okazja. W liście z Nowego Jorku datowanym na 29 maja I949 r. poeta pisal:

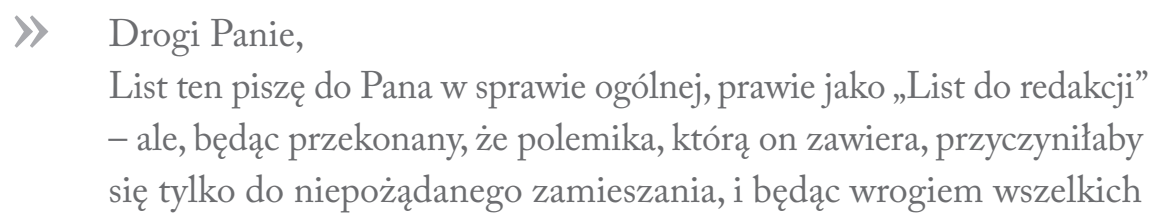

33 Ibidem.

34 Pierwodruk: „Nowiny Literackie” 1948, nr 19, s. 2; potem w tomie: Ody olimpijskie, Warszawa 1948.

35 W wierszu czytamy m.in. następujące frazy: „O olimpijski zwycięzco! Dlaczego cię nie ma z nami $\mathrm{w}$ tej chwili? Dlaczego nie chcesz z nami odgarniać kamieni zburzonej stolicy [...]? Dlaczego nie walczysz razem z nami? [...] Dlaczego nie odprawiasz obrzędów oczyszczenia, jak trzeba, przyjacielu, jak trzeba? Czyż nie słyszysz głosów, które do ciebie przez ocean wołają? Czyli nie słyszysz wołania? To matka twoja woła, matka zabita w mogile leżąca na przedmieściu zburzonym, jak ptak kwili, brat w więzieniu zamęczony krwią się oblewa. [...] Jakiż wróg przekopał między nami przedział? Jak nazwać tego, który tak straszne odkrył przed tobą obrazy, iż nie chcesz patrzeć w stronę, gdzie ojciec twój spoczął w mogile? Któż ci tak niedobrze powiedział [...]. Zła myśl, zły czyn odgrodziła cię ode mnie, od Warszawy, od prawdziwej ojczyzny. [...] Nie dąsaj się na pustkowiach ludnej Ameryki! [...] Powracaj i wznoś razem z nami olimpijskie okrzyki: O pokój, pokój, pokój prosimy cię, Panie! A jeśli pokój śmiercią trzeba okupić, a życie mogiłą, Prawda po naszej jest stronie i prawda jest siłą!”.

36 M.in. Aleksander Janta-Połczyński pisał: „[Lechoń] próbował przekonać Giedroycia dwudziestostronicowym listem, że idzie fałszywą drogą, drukując w r. 1949 moją relację o pobycie w Polsce i obronę jej, zamieszczoną na tych samych łamach, pióra Zbigniewa Florczaka” (A. Janta, Nowe odkrycie Ameryki, Paryż 1973, s. 79).

37 Druk fragmentów w: M. Grydzewski, J. Lechoń, Listy 1923-1956, op. cit., t. 1, s. 232-233. 
środowisk publicznych dyskusji, niewyjaśniających niczego. Proszę Pana, aby treść tego listu pozostała między mną a Panem, czy między mną, Panem a Czapskim. Myślę, że w ten sposób cel jego zostanie osiągnięty.

Chciałem do Pana pisać zaraz po ukazaniu się w „Kulturze” reportażu Janty, ale kiedy dalsze jego artykuły zostały wstrzymane ${ }^{38}$ uważałem tę wysyłkę za szczęśliwie niepotrzebną i z radością z niej zrezygnowałem.

Artykuł pana Florczaka ${ }^{39}$, uhonorowany pomieszczeniem go na pierwszym miejscu zmienia, niestety, mój pogląd, stawiając mnie wobec poparcia Janty przez „Kulturę” - faktu, do którego zdecydowanie ustosunkowałem się wewnętrznie. Nie jest dla mnie możliwe zataić tę moją zniewagę [?] przed Panem - tak jak byłoby mi bardzo ciężko publicznie w tej sprawie wystąpić. Może więc Pan zechce ten list przeczytać jako list przyjacielski Polaka, dla którego takie czy inne myśli i uczucia Polaków są rzeczą bardzo istotną i ważną, który nie szuka łamów polemisty, ale który bardzo chciałby być zrozumiany i może nawet wysłuchany przez życzliwych.

Muszę tedy powiedzieć Panu po prostu, że artykuł i książkę Janty uważam za napisane świadomie czy nieświadomie pod dyktando bolszewickie i że obrona jego w „Kulturze” wydaje mi się rzeczą w najwyższym stopniu gorszącą i bardzo szkodliwą dla i tak zdezorientowanej i zdemoralizowanej opinii polskiej na emigracji. Moja opinia o Jancie opiera się na pewnym talencie, który sobie przypisuję, instynktownego syntetyzowania wrażeń z lektury. Oczywiście, że tę syntezę podjąłbym się cytatami obronić. Ale nie uważam tego za potrzebne. Na dwa lata przedtem zanim Tuwim oficjalnie przystał do tego wtenczas „Lublina”, zerwałem z nim wieloletnią przyjaźń, pisząc mu, że przeszedł on granicę tych różnic poglądów, które przyjaźń

38 A. Janta-Połczyński, Wracam z Polski, „Kultura” 1948, nr 10. Reportaż był pokłosiem podróży odbytej latem 1948 r. do kraju, a jego publikacja stała się w środowiskach emigracyjnych wydarzeniem graniczącym ze skandalem; w rezultacie generał Anders zakazał Giedroyciowi drukowania dalszych jego części na łamach „Kultury”, jednocześnie polecając wstrzymanie kolportażu kwestionowanego numeru; ostatecznie rok później Giedroyc wydał całość z własnych funduszy.

39 Z. Florczak, Examen libre, „Kultura” 1949, nr 2. - W artykule autor krytykował fakt negatywnego przyjęcia przez emigrację książki Janty Wracam z Polski (Paryż 1949), w której przedstawiał on własną wizję powojennej rzeczywistości w Polsce, a następnie zaatakował Zygmunta Nowakowskiego za jego niezwykle krytyczną recenzję „Wielki spowiednik”, „Wiadomości” 1949, nr 16/17 (159/160) z 24 kwietnia, uznając wprawdzie znakomite walory pióra Nowakowskiego, ale oceniając jego publicystykę jako szkodliwą politycznie. 
może wytrzymać ${ }^{\circ}$. Na mój prywatny użytek nie mam też żadnych wątpliwości co do znaczenia i wartości tego, co napisał Janta. Nie chciałbym też popaść w taką perwersję, aby się nad tym jeszcze zastanawiać. Sprawa Janty jest oczywiście o tyle różna, że Tuwim jest i zostanie na zawsze pomimo wszystko wielkim poetą, a Janta jest i prawdopodobnie zostanie na zawsze drugorzędnym dziennikarzem. Tym mniej rozumiem stanowisko Pana i to honorowe miejsce, jakie dali Panowie w „Kulturze” sprawie, która, myślę, powinna była być szybko zapomniana. Artykułu pana Florczaka, o którym zresztą nic nie wiem - po prostu nie rozumiem. Nie rozumiem, jak można, tak jak on pisać o Nowakowskim, który mimo wszelkich swoich kaprysów jest jedną z niewielu trwałych i szlachetnych ideowo i pisarsko pozycji naszej emigracji, może po Matuszewskim najtrwalszą. Być może Pan uzna to za arogancję, kiedy powiem, że jestem pewny, iż kilkanaście artykułów Nowakowskiego zostaną na zawsze jako ozdoba polskiej publicystyki i myśli politycznej. Czy pan Florczak na pewno przeminie bez echa, tego nie wiem - ale jeśli chodzi o moje zdolności zrozumienia i odczucia polskiego słowa pisanego, to muszę stwierdzić, że dotychczas nie czytałem nic z jego podpisem, co by nie było bądź niepotrzebnie zawikłane, bądź banalne, bądź, jak to mówią, „kula w płot”. Spowiadam się Panu najszczerzej: nie rozumiem, jak można, pisząc tak jak pan Florczak - tak pisać o Nowakowskim. Oczywiście te wątpliwości mógłby ktoś prze[---]yć, mówiąc, że ja się właśnie nie znam na pisaniu. Ten list do Pana piszę w złudnym może przeświadczeniu, że Pan nie jest tego zdania.

Myślę najszczerzej, że obrona pewnej hierarchii artystycznej i ludzkiej była zawsze potrzebą polskiego życia, a na emigracji jest nią w dwójnasób. Dlatego również artykuł pana Florczaka uważam za gorszący, uważam go za objaw złych obyczajów; oczywiście dlatego, że najszczerzej cenię wysoko Nowakowskiego. Stosunek tego Pana zarówno do tak, zdawało mi się, szczególnych wartości i zasług Nowakowskiego, jak do żałosnej sprawy Janty, wydaje mi się przecież objawem pewnej tendencji umysłowej, która, śmiem tak myśleć, odegrała już straszną rolę w poddaniu się na całym świecie „klerków” różnym „koniecznościom” i w zaprzepaszczeniu przez polskich intelektualistów wielkiej moralnej linii, która była nie tylko chlu-

40 Mowa o liście J. Lechonia do J. Tuwima z 29 maja 1942 r.; zob. B. Dorosz, Lechoń i Tuwim - dzieje trudnej przyjaźni, Warszawa 2004, s. 44-46. 
bą polskiej myśli, ale jednym ze skarbów, tak patetycznie mówiąc, „polskiej duszy”.

W swoim artykule o Wańkowiczu napisał Czapski, że zawsze go zastanawiała pewność jego Ojca - że coś tak powinno być albo być nie powinno. Uważam, że bez tej pewności nie byłoby ani Mickiewicza, ani Słowackiego, ani P[---], ani Piłsudskiego. Krańcowym przeciwieństwem tego wyznawanego stosunku do życia (i literatury zresztą) jest relatywizm, z najróżniejszych pobudek płynący, który chce wszystko rozpatrywać i rozumieć, choć przecież są rzeczy niewymagające ani dyskusji, ani dociekań i po prostu bijące w oczy. Jako powieściopisarz mogę analizować psychologię zdrady, ale jako publicysta muszę to pojęcie uważać za pewien absolut, z którym nie może być żadnych polemik tylko walka. „Kultura” z bardzo szlachetnych pobudek wzięła sobie, zdaje się, za zadanie - „nie odchodzić od Kraju”. Rozumiem i cenię to pragnienie - ale jego realizacja wydaje mi się niemożliwa i nieraz niebezpieczna. Przecież [?] możemy sobie powiedzieć, że „kraj” to już, jeśli chodzi o literaturę, nie jest nie tylko Żeromski, ale i Kaden, że „kraj” to jest Nałkowska, Pruszyński, [---]. Staff na pewno nie myśli, że „odszedłem od niego”, dlatego że nie drukuję w „Czytelniku”, na pewno myśli wręcz przeciwnie. A jak „nie odejść” od przymusowego świństwa Iwaszkiewicza czy Gałczyńskiego, czy Andrzejewskiego, czy teraz nawet Żukrowskiego. Myślę, że to nasze zadanie - aby, jedząc bardzo ciężki chleb emigracji, „odejść” od tego, co jest straszliwie narzuconym krajowi upodleniem. Przyznam się, że stanowisko „Kultury” w tych sprawach, których tu bezładnie i bardzo grubo dotykam - jest dla mnie szczerze ciężkim przeżyciem. Widzę w nim pewien fenomen, bardzo charakterystyczny dla ludzi, którzy sami mieli okazję i wolę coś poświęcić, coś moralnie pięknego zdziałać w życiu. Zdawałoby się, że taki dorobek uzbraja człowieka w możność sądzenia twardo spraw i ludzi, co jest w naszym dzisiejszym życiu tak ważne i potrzebne. Panowie macie pewnie prawa, których mnie można bardzo łatwo odmówić. „Nie byłeś, nie cierpiałeś, nie masz prawa sądzić”. Otóż może się mylę, ale mam wrażenie, że wielu Polaków, którzy przeszli przez Rosję, wojnę, powstanie - czerpie $\mathrm{z}$ tego usprawiedliwienie do luksusu relatywizmu i pobłażania. „Mnie nikt nie będzie mógł zarzucić, ja mogę pobłażać bo mam za sobą rany, obozy, podziemie". Myślę, że Pan mnie dobrze zrozumie, że Pan nie wątpi na chwilę, iż wiem, że u ludzi Pana i Pana przyjaciół typu ta tendencja, jeśli się przejawia, jest wyrazem najbardziej szlachetnych i subtelnych odruchów. Ale niech Pan pomyśli, że 
cały „pétainizm” wyrósł właśnie z tego, że Pétain uważał: ,ja byłem pod Verdun, ja mogę się poddać”. Przecież za Pétainem poszedł nie tylko kanalia Drieu La Rochelle i szmata Chardonne, ale i szlachetny, ale jakże relatywistyczny Halevy. Ach! Jakby to było dobrze, żeby Pan uwierzył w głęboką i ważną przyjaźń, jaka mi dyktuje te słowa i każe mi snuć aż tak krańcowe parabole.

Nasza emigracja jest to nie zorganizowane, ale coraz bardziej zdezorganizowane nieszczęście. Klęska literatury i sztuki jest w tym naszym strasznym życiu jednym z najcięższych przeżyć i najobrzydliwszych widowisk. Nie mogę się już zmienić po pięćdziesiątce - więc sobie wyobrażałem, że paru ludzi zgromadzi się wokół paru prawd, nie do zachwiania i nie do dyskusji, prawd, których absolut jest według mego [---] tu sensem tragicznym i najcięższym estetycznym [---] życia. Artykuł pana Florczaka na czele „Kultury” jest daniem „łopatą po głowie" tym marzeniom. Według moich pojęć i obyczajów, gdyby Panowie umieścili w następnym numerze polemikę z tym artykułem - nie zmieniłoby to nic w tej sprawie. Wyspiański, którego mógłbym i chciałbym jak Nowakowski cytować bez końca, powiada coś w tym rodzaju: „A! Naturalnie! Powinna być cenzura narodowa”. I boję się, że jeśli nie będzie cenzury [---] Nowakowskiego, to zostanie nam tylko cenzura Paskiewicza. Proszę, drogi Panie, wierzyć w moją prawdziwą przyjaźń i przyjąć bardzo serdeczne słowa dla siebie i Czapskiego od Jana Lechonia ${ }^{4 \mathrm{I}}$.

Nic chyba zatem dziwnego, że tak wyłożywszy redaktorowi Giedroyciowi swoje polityczne stanowisko, wkrótce potem w liście z 20 września 1949 r. pisał Lechoń do redaktora Grydzewskiego: „Jak wiesz, nie chcę drukować w «Kulturze» i zostają mi tylko «Wiadomości»" ${ }^{2}$.

Wróćmy jednak do „pomysłu z «dziennikiem» à la Gide”. Zerwanie kontaktów na tle politycznym zniweczyło pomysł publikacji dziennika Lechonia w „Kulturze”ale gdyby się to udało, to Lechoń, a nie Gombrowicz byłby pierwszym w literaturze polskiej autorem, który na bieżąco publikował swój dziennik.

41 Oryginał znajduje się z Bibliotece Narodowej w Warszawie, Dział Rękopisów, sygn. Akc. 016101, t. 1; koperta opatrzona jest uwagą (nieustalonego autorstwa): „Pasterski list Jana Lechonia do redaktora «Kultury» w sprawie Janty, Florczaka et consortes”; list pisany jest na czterech arkuszach papieru listowego, co stanowi osiem stron tekstu. - W obecnej edycji słowa nieodczytane z rękopisu oznaczone są [---], a odczytane hipotetycznie opatrzone są [?].

42 M. Grydzewski, J. Lechoń, Listy 1923-1956, op. cit., t. 1, s. 257. 
Ciekawe, że cztery lata później Gombrowicz, zapytując Giedroycia o możliwość druku osobistych zapisków, także odwoływał się do doświadczeń wyniesionych z lektury Gide'a:

\section{\Piszę teraz coś w rodzaju Dziennika [...]. Journal Gide'a nie tyle mnie natchnął, ile ukazał mi możliwość przezwyciężenia pewnych zasadniczych trudności, które dotąd mi realizacje tego projektu unie- możliwiały (bo ja myślałem, że Dziennik musi być «prywatny», a on mi odkrył możliwość prywatno-publicznego dziennika) ${ }^{43}$.}

A odpowiedź uzyskał niemal identyczną jak Lechoń: „Pomysł Dziennika jest b. dobry. Jest to forma wymarzona dla Pana" ${ }^{44}$.

To jednak czas już nieco późniejszy. O możliwych innych scenariuszach na przełomie lat czterdziestych i pięćdziesiątych na podstawie faktów ujawnionych w różnorodnej korespondencji pisał też Wojciech Wyskiel:

\Wiele spraw mogło się ułożyć inaczej. Na przykład: jeszcze w I95I roku redaktor „Kultury” nie był zdecydowany na współpracę z Gombrowiczem, ten ostatni zaś liczył raczej na pomoc z kręgu „Wiadomości”. Szukał więc wsparcia u zaprzyjaźnionego z Lechoniem Wittlina ${ }^{45}$.

I na potwierdzenie tej tezy cytował dalej list Gombrowicza do Józefa Wittlina z 26 lutego 195I r., w którym znajdował się znamienny fragment:

\ Niezmiernie będę Panu wdzięczny, jeżeli napisze Pan do Giedroycia. Dowiedziałem się właśnie od Pawła Zdziechowskiego, że nie chce on drukować moich rzeczy w „Kulturze”, gdyż ma nawał aktualnego materiału - ale Paweł jest zdania, że Giedroyc dałby się namówić, gdyby mu dobrze i w sposób autorytatywny wyperswadowano, że utwór jest ważny. [...] Posyłam też tekst Grydzewskiemu z propozycją, aby go ogłosił w całości. Czy nie byłoby z mojej strony nadużyciem, gdybym prosił Pana o napisanie do niego także? ${ }^{46}$

43 List W. Gombrowicza do J. Giedroycia z 6 sierpnia 1952 r., w: J. Giedroyc, W. Gombrowicz, Listy 1950-1969, op. cit., s. 84.

44 List J. Giedroycia do W. Gombrowicza z 11 sierpnia 1952 r., ibidem, s. 85.

45 W. Wyskiel, Kregi wygnania. Jan Lechoń na obczyźnie, op. cit., s. 181.

46 Wyskiel cytował list wówczas niepublikowany z archiwum Józefa Wittlina w Harvard University w Cambridge; tu cyt. za: Gombrowicza walka o stawę. Korespondencja Witolda Gombrowicza z Jozefem Wittlinem, Jarostawem Iwaszkiewiczem, Arturem Sandauerem, oprac. J. Jarzębski, Kraków 1996, s. 22. 
Ostatecznie badacz konstatował: „A więc i tak było: Giedroyc zabiegał o współpracę Lechonia i zwlekał z odpowiedzią Gombrowiczowi" ${ }^{47}$. Wydaje się zatem, że przedstawiona tu „Giedroyciowo-Lechoniowa historia alternatywna” poruszyła nie tylko moją wyobraźnię i nie tylko mnie wydała się wcale prawdopodobna.

Jeśli dodam do tego informację, że także o cztery lata wyprzedził Lechoń przekład powieści Orwella Rok 1984, tłumacząc i adaptując ją na cykliczne słuchowisko radiowe nadane jesienią 1949 r. przez Voice of America, natomiast wydane przez Instytut Literacki tłumaczenie Mieroszewskiego ukazało się dopiero w roku 1953 ${ }^{48}$ - można zaryzykować opinię, że „konstelację «Kultury»”49 ominęła - ze szkodą dla obu stron - samotnie dryfująca po literackim nieboskłonie „kometa Lechonia” ${ }^{\circ}$.

Podział emigracji na „frakcję” londyńską i paryską był faktem - zakorzenił się też dość trwale w opisujących polską diasporę opracowaniach historyków i literaturoznawców. Można wszak zaryzykować tezę, że cytowane w przedstawianym tekście listy, dotychczas niepublikowane, dość wyraziście pokazują środowisko wychodźcze w chwili „tuż przed podziałem”, targane konfliktami i hołdujące różnym wyobrażeniom na temat misji, jaką wobec idei prawdziwej niepodległości i suwerenności Polski oraz wolnej polskiej kultury miała pełnić emigracja. Wydaje się, że dzięki tej korespondencji możliwe jest zajrzenie poniekąd za kulisy wydarzeń, a historia - zapisana $\mathrm{w}$ listach expressiss verbis - objawia się w nich $\mathrm{z}$ całą swoją dynamicznością i złożonością.

\section{Bibliografia:}

Anders Wł., [Rozkaz z 11 lutego 1946 r. i inne wymienione w tym tekście], archiwum Instytutu Literackiego w Maison Laffitte, sygn. ILR 03 (nazwa zespołu i numer teczki: Instytut Literacki Rzym, t. 03);

Dorosz B., Lechoń i Tuwim - dzieje trudnej przyjaźni, Warszawa 2004;

Orwell wedtug Lechonia (polska premiera), „Archiwum Emigracji” 2013, z. (2) 19, s. 7-28;

Poeta "do ustug” w objeciach „wielkiego manipulatora” (na marginesie korespondencji Kazimierza Wierzyńskiego zJerzym Giedroyciem), „Sztuka Edycji” 2015, nr 2, s. 5-15;

47 W. Wyskiel, Kregi wygnania. Jan Lechoń na obczyźnie, op. cit., s. 182.

48 Szerzej o tym zob. B. Dorosz, Orwell wedtug Lechonia (polska premiera), „Archiwum Emigracji” 2013, z. (2) 19, s. 7-28; tu też pierwodruk adaptacji.

49 P. Kłoczowski, Konstelacja „Kultury”. Artystyczne wybory Redaktora, rozm. T. Fiałkowski, „Tygodnik Powszechny” 2006, nr 40. Takiego określenia użył Kłoczowski w odniesieniu do Józefa Czapskiego, Gustawa Herlinga-Grudzińskiego, Witolda Gombrowicza, Konstantego Jeleńskiego, Czesława Miłosza i Jerzego Stempowskiego, łącząc ich z najlepszym - jego zdaniem - okresem „Kultury”: trzema dekadami lat pięćdziesiątych, sześćdziesiątych i siedemdziesiątych XX wieku.

50 Tym bardziej rozczarowujący to przypadek, bo przecież już w $1948 \mathrm{r}$. jako baczny obserwator i krytyczny diagnosta współczesnej polityki Orwell był obecny na łamach „Kultury” w esejach: Lew i nosorożec ( $\mathrm{nr} 4)$ na temat Anglii tracącej status imperium, Środki zapobiegawcze w literaturze (nr 5) na temat cenzury politycznej wobec współczesnej europejskiej twórczości literackiej. 
Florczak Z., Examen libre, „Kultura” 1949, nr 2;

Giedroyc J., Autobiografia na cztery rece, oprac. K. Pomian, Warszawa 1994;

Giedroyc J., Bobkowski A., Listy 1946-1961, oprac. J. Zieliński, Warszawa 1997;

Giedroyc J., Gombrowicz W., Listy 1950-1969, oprac. A.S. Kowalczyk, Warszawa 2006;

Giedroyc J. do Lechonia J., list, archiwum Jana Lechonia w Polskim Instytucie Naukowym w Ameryce, kolekcja: Jan Lechoń Papers - 005, folder 28;

Giedroyc J. do Lechonia J., archiwum Maison Laffitte: Korespondencja Redakcji - teka 409. ILK KOR RED. Lechoń;

Giedroyc J., Wańkowicz M., Listy 1945-1963, oprac. A. Ziółkowska-Boehm, J. Krawczyk, Warszawa 2000;

Giedroyc J. do Wierzyńskiego K., listy, archiwum K. Wierzyńskiego w Bibliotece Polskiej w Londynie, sygn. 1360/Rps/VI/1e;

Gombrowicza walka o stawę. Korespondencja Witolda Gombrowicza z Jozefem Wittlinem, Jarostawem Iwaszkiewiczem, Arturem Sandauerem, oprac. J. Jarzębski, Kraków 1996;

Grydzewski M., Lechoń J., Listy 1923-1956, oprac. B. Dorosz, t. 1-2, Warszawa 2006;

Grydzewski M. do Wierzyńskiego K., listy, archiwum K. Wierzyńskiego w Bibliotece Polskiej w Londynie, sygn.: 1360/Rps/VI/1.f1;

Silva rerum, oprac. J.B. Wójcik, M.A. Supruniuk, Warszawa 2014;

Habielski R., Mapa Maisons-Laffitte (Giedroyc i Londyn), w: Jerzy Giedroyc: kultura-polityka - wiek XX, pod red. A. Mencwela, Warszawa 2009, s. 339-367;

Nieztomni nieprzejednani. Emigracyjne „Wiadomości” i ich krag 1940-1981, Warszawa 1991, s. 7-8;

Herling-Grudziński G. do Lechonia J., list, archiwum Jana Lechonia w Polskim Instytucie Naukowym w Ameryce, kolekcja: Jan Lechoń Papers - 005, folder 22;

Iwaszkiewicz J., Ody olimpijskie: Oda druga. Do dawnego zwycięzcy zawodów olimpijskich, „Nowiny Literackie" 1948, nr 19;

Ody olimpijskie, Warszawa 1948;

Janta-Połczyński A., Wracam z Polski, „Kultura” 1948, nr 10;

Kłoczowski P., Konstelacja „Kultury”. Artystyczne wybory Redaktora, rozm. T. Fiałkowski, „Tygodnik Powszechny" 2006, nr 40;

Kowalczyk A.S., Od Bukaresztu do Laffitów: Jerzego Giedroycia rzeczpospolita epistolarna, Sejny 2006;

Lechoń J. do Giedroycia J., list, archiwum w Maison Laffitte: Papiery osobiste Jerzego Giedroycia - korespondencja. ILK PoJG 08.01. Lechoń;

Lechoń J. do Giedroycia J., list, Biblioteka Narodowa w Warszawie, Dział Rękopisów, sygn. Akc. 016101, t. 1;

Listy Kazimierza Wierzyńskiego i Jerzego Giedroycia: cztery listy spośród czterystu czterdziestu listów, oprac.

B. Dorosz, „Sztuka Edycji” 2015, nr 2, s. 95-103;

Nowakowski Z., „Wielki spowiednik”, „Wiadomości” 1949, nr 16/17 (159/160);

Orwell G., Lew i nosorożec, „Kultura” 1948, nr 4;

Środki zapobiegawcze w literaturze, „Kultura” 1948, nr 5;

Pankowski M., Wolny od tzy, „Kultura” 1957, nr 7-8;

WB [Borzęcki Wł.], Pięknie uczczono 30-lecie pracy twórczej Jana Lechonia, „Nowy Świat” (Nowy Jork) 1948, nr z 23 lutego;

Wyskiel W., Kreggi wygnania. Jan Lechoń na obczyźnie, Kraków 1988. 
SŁowa KLucze: Jerzy Giedroyc, Mieczysław Grydzewski, Jan Lechoń, Kazimierz Wierzyński, „Kultura”, „Wiadomości”

\section{Beata Dorosz}

„WHAT IF...”- ABOUT (TWO) POSSIBLE AND NOT UNACCOMPLISHED EMIGRATION STORIES

The text is based on unpublished letters between Mieczysław Grydzewski and Kazimierz Wierzyński and between Jerzy Giedroyc and Jan Lechoń. It gives an account of the talks in 1946 about potential publishing a magazine by Grydzewski in Rome under the auspices of and Polish Corps (talks held before establishing „Kultura” in 1947) and also of the efforts made to gain Lechon as a co-worker for the periodical and discussions about printing in „Kultura” the poet's journal (it was earlier than the printing of Witold Gombrowicz's journal in 1953). The cited extensive letters are a testimony of unknown events from the culture-literary life of Polish pro-independence emigration after World War II.

Key words: Jerzy Giedroyc, Mieczysław Grydzewski, Jan Lechoń, Kazimierz Wierzyński, „Kultura”, „Wiadomości” 